\title{
The Society for Serving Humanity and Its Tree-planting Project
}

$\mathrm{T}^{\mathrm{h}}$ he Society for Serving Humanity, a registered nongovernmental organization having its headquaters at Sempatti, has been operating in the Anna District of Tamil Nadu, India, since 1988. It has undertaken many development-oriented projects such as eco-farming, agro-forestry, and environmental education for youth and small farmers in this region, towards achieving its motto of 'Integrated Human Development'.

The Society has adopted 30 villages for child-care and has established evening schools for educating working and drop-out children. A self-employment programme for women under the guidance of the Society has been wellappreciated and a conspicuous success in this region.

Apart from having adequate infrastructural facilities, the Society is capable of employing 30 women and 10 men development workers at present. The rural masses have been motivated and organized into groups from which 45 women's development committees have emerged. These groups have already begun to show positive results by their very understanding and solving of developmental issues in this region.

It is said that Man, apart from being united among himself, must be united with the environment if he is to make his life safer and better on the face of the Earth. Yet more than ever before environmental degradation has become a crisis facing today's world. There seems to be a global warning that Mankind will end up in frustration or worse if committing of crimes against Nature continues. It is a relevant fact that Man has progressed at the cost of the environment that sustains him. Destruction of trees and vital forests has become the order of the day.

In our country, too, the situation is the same. Every day about ten million trees are cut down in India. The apparent results are poverty and famine in some parts of the country - not caused by any natural disasters but by Man. Hence the need to take preventive measures becomes essential. Tree plantation on a large scale may be the only possible solution to combat the present situation, and we are ready, along with the local people and government authorities, to undertake this task.

Tree plantation and prevention of environmental degradation go hand-in-hand. Our project of primary concern is just a sample of what needs to be done on a permanent basis in future for preserving natural resources in this region. The project, which is planned for three years, will make use of all locally available resources for its further active continuation provided we find the necessary support of half-a-million rupees.

A. Britto SelvaraJ, Secretary Society for Serving Humanity Palani Road Sempatti Anna District Tamil Nadu, India.

\section{Fields Pond Foundation Serving Grassroots Conservation Groups}

$\mathrm{T}$ hink Globally, Act Locally', admonishes a bumper sticker that is popular in the United States. To the newly-formed Fields Pond Foundation, this idea forms its guiding principle: that the greatest successes in environmental conservation can be achieved by small-scale local efforts, and by the elevation of awareness levels that arises from the involvement of the local populace in such efforts.

Grassroots (bottom-up) groups, by their very nature, are closest to the issues and are best able to achieve meaningful conservation; at the same time, they are among the least equipped to identify and draw on the tools and funding sources which may be available to help them reach their objectives. Fields Pond Foundation will act as a conduit in providing these institutions with much-needed support.

The primary focus of the Foundation will be to aid in the establishment of endowments for specific environmental projects, generally in the form of matching or seeding grants. Among the many needs that have already been brought to our attention may be cited:

- A Marine Adventure Programme provides a camping experience for young people between the ages of eight and sixteen, helping them to understand and appreciate the environmental, economic, and cultural, values $e . g$. of the local river and estuary with its adjoining shoreline. Participants in that case will literally get their feet wet when examining marine and shoreland habitats and communities, and mapping the river's estuary system. Expansion of the programme requires a reliable source of funding; a programme-specific endowment is accordingly called-for.

- The Roseate Tern (Sterna dougallii), an endangered species, once proliferated in the coastal zone of a northeastern US peninsula, until development of shoreland sites and of nearby islands eliminated its favoured nesting-places. An opportunity now exists to reintroduce the Roseate Tern to a critical former nesting-area: a recent fire destroyed the development, and the island is under consideration for eventual inclusion in the Petite Manan Federal Wildlife Sanctuary. But as the federal Fish and Wildlife Agency cannot act as quickly as potential new developers, it is incumbent on local environmental leaders to devise an immediate plan to conserve these islands. A low-interest Foundation loan, backed by a local 'challenge grant' programme, would secure this sensitive area for eventual protection and participation by the federal Agency.

Worthy efforts such as these can best be supported by funding methods that serve to engage local supporters in both the environmental issues and the funding process. The Foundation will also make direct grants for specific projects including land acquisition, trail building and maintenance, enhancement of public access, environmental education, and guidebook publication.

Fields Pond Foundation has achieved US charitable status recognition and is in the process of raising capital by encouraging response among individuals and larger conservation trusts (both in Europe and the US) that are sympathetic to the goal of nurturing these vital local organizations.

Grant applications will be accepted for consideration in the fall of 1994 for awards to begin in 1995. During this initial funding year, preference will be given to activities in the New England region of the US.

LEON H. CoHEN, President Fields Pond Foundation, Inc. 11 Rumford Avenue, Suite $3 C$ Waltham

Massachusetts 02254-0667, USA. 